\title{
Penerapan Kebijakan K3 Yang Berkaitan Dengan Keperawatan \\ Di Indonesia
}

\author{
Riana Silvia Casuarina L.Tobing \\ riana.sct@gmail.com
}

\section{Latar Belakang :}

Keselamatan dan kesehatan kerja merupakan suatu pemikiran dan upaya untuk menjamin keutuhan dan kesempurnaan baik jasmani maupun rohani. Dengan keselamatan dan kesehatan kerja maka para pihak diharapkan tenaga kerja dapat melakukan pekerjaan dengan aman dan nyaman serta mencapai ketahanan fisik, daya kerja, dan tingkat kesehatan yang tinggi. Keselamatan dan kesehatan kerja adalah kegiatan yang dirancang untuk menjamin keselamatan dan kesehatan di tempat kerja. Perawat berisiko terhadap kecelakaan dan penyakit akibat pekerjaan. Tujuan penelitian ini menganalisis pengaruh faktor predisposing,enabling, reinforcing dan core-care terhadap keselamatan dan kesehatan kerja pada perawat dalam penanganan pasien, Standar Kesehatan dan Keselamatan Kerja di RS (K3RS) perlu ditetapkan untuk mencegah dan mengurangi risiko kecelakaan dan penyakit akibat kerja di RS.Demi terciptanya jaminan keselamatan kerja maka diperlukan pelayanan strategis yang profesional serta prosedur kerja yang tetap, tidak hanya tergantung pada peraturan-peraturan yang mengayominya dan finansial yang diberikan, melainkan banyak faktor yang harus ikut terlibat, diantaranya adalah pelaksanaan organisasi.Suatu organisasi yang berhasil dapat diukur dengan melihat pada sejauh mana organisasi tersebut dapat mencapai tujuannya.Pelaksanaan K3 di RS dapat dinilai dari kefektivitasan organisasi K3 tersebut. rumah sakit sebagai industri jasa yang mempunyai beragam persoalan tenaga kerja yang rumit dengan berbagai risiko terkena penyakit akibat kerja bahkan kecelakaan akibat kerja sesuai jenis pekerjaannya, sehingga berkewajiban menerapkan upaya Keselamatan dan Kesehatan Kerja Rumah Sakit (K3RS). Namun, cenderung ditemukan bahwa kebijakan, perencanaan serta pelaksanaan K3RS tampaknya belum terlaksana secara maksimal sesuai standar, sehingga pekerja rumah sakit banyak mengalami masalah kesehatan dan keselamatan kerja. 
Rumah sakit merupakan sarana kesehatan yang menyelenggarakan pelayanan kesehatan, tempat berkumpulnya orang sehat dan sakit sehingga risiko kemungkinan terjadinya gangguan kesehatan dan penularan penyakit sangat tinggi. Oleh sebab itu, diperlukannya penerapan Keselamatan dan Kesehatan Kerja Rumah Sakit (K3RS) untuk mencegah terjadinya potensi bahaya tersebut.

\section{Tujuan :}

Untuk Mengetahui dan memehami Penerapan Kebijakan K3 yang berkaitan dengan Keperawatan di Indonesia terutama Kebijakan K3 yang diterapkan oleh Rumah Sakit (K3RS).

\section{Metode:}

Artikel Ilmiah ini berdasarkan tinjauan sistematik dari beberapa artikel jurnal penelitian yang dipublikasi pada basis elektronik menggunakan metode tersearch dan analisis dari berbagai sumber seperti buku teks, buku referensi jurnal, dan ebook, dengan menggunakan Google Scholar,Portal Garuda dan Jurnal Keperawatan Indonesia. Yang Penerapan Kebijakan K3 yang berkaitan dengan Keperawatan di Indonesia serta bagaimana penerapan yang diterapkan oleh rumah sakit.

\section{Hasil:}

Rumah sakit merupakan tempat kerja berisiko. Pekerja rumah sakit mempunyai risiko lebih tinggi dibandingkan dengan pekerja industri lain untuk terkena penyakit akibat kerja (PAK) dan kecelakaa akibat kerja (KAK) (1). Bahaya potensial di rumah sakit disebabkan oleh faktor biologi (virus, bakteri, jamur), faktor kimia (gas anestesi, bahan kimia berbahaya), faktor ergonomi (posisi mengangkat beban yang salah), faktor fisik (pencahayaan, bising, getaran, suhu), serta faktor psikososial (hubungan antara rekan kerja yang kurang baik, jam kerja terlalu lama). Bahaya dari faktor-faktor tersebut dapat menyebabkan kecelakaan kerja maupun penyakit akibat kerja yang dapat menyebabkan penurunan kemampuan fisik atau mental,cacat, bahkan kematian. Hal ini dapat merugikan rumah sakit sebagai tempat kerja. Kesehatan dan Keselamatan Kerja (K3) 
merupakan suatu upaya perlindungan kepada tenaga kerja dan orang lain yang memasuki tempat kerja terhadap bahaya dari akibat kecelakaan kerja. Tujuan K3 adalah mencegah, megurangi, bahkan menihilkan resiko penyakit dan kecelakaan akibat kerja (KAK) serta meningkatkan derajat kesehatan para pekerja sehingga produktivitas kerja meningkat.Dalam Undang-Undang Republik Indonesia Nomor 36 Tahun 2009 Tentang Kesehatan, upaya kesehatan kerja ditunjukkan untuk melindungi pekerja agar hidup sehat dan terbebas dari gangguan kesehatan serta pengaruh buruk yang diakibatkan oleh pekerjaan sehingga sudah seharusnya pihak pengelola RS menerapkan upaya-upaya K3 di RS. K3 termasuk sebagai salah satu standar pelayanan yang dinilai di dalam akreditasi RS, disamping standar pelayanan lainnya. Pekerja RS mempunyai risiko lebih tinggi dibanding pekerja industri lain untuk terjadinya Penyakit Akibat Kerja (PAK) dan KAK, sehingga perlu dibuat standar perlindungan bagi pekerja yang ada di RS.4 Untuk mencegah dan mengurangi resiko bahaya tersebut maka perlu ditetapkan standar K3 di RS. Perlunya pelaksanaan K3RS mengenai kebijakan pemerintah tentang RS di Indonesia adalah untuk meningkatkan akses, keterjangkauan, dan kualitas pelayanan kesehatan yang aman diRS. Perencanaan, pelaksanaan, monitoring, dan evaluasi K3 RS serta tindak lanjut, yang merujuk pada SK Menkes No. 432/ Menkes/ SK/ IV/ 2007 tentang Pedoman Manajemen K3 di RS dan OHSAS 18001 tentang Standar Sistem Manajemen K3. Sistem manajemen K3RS adalah bagian dari sistem manajemen RS. Pelaksanaan K3, berkaitan dengan citra dan kelangsungan hidup RS. Manajemen adalah proses perencanaan, pengorganisasian, pengarahan dan pengawasan usaha para anggota organisasi dan pengguanaan sumber daya organisasi lainnya agar mencapai tujuan organisasi yang telah ditetapkan. Kementerian Kesehatan Republik Indonesia mewajibkan dilaksanakannya akreditasi RS dengan tujuan untuk meningkatkan pelayanan RS di Indonesia.Standar akreditasi yang digunakan saat ini akan menekankan pada pelayanan berfokus pada pasien serta kesinambungan pelayanan dan menjadikan keselamatan pasien sebagai standar utama serta melibatkan seluruh petugas dalam proses akreditasi. 


\section{Pembahasan :}

Perawat adalah suatu profesi yang mulia, karena memerlukan kesabaran dan ketenangan dalam melayani pasien yang sedang menderita sakit. Seorang perawat harus dapat melayani pasien dengan sepenuh hati. Sebagai seorang perawat harus dapat memahami masalah yang dihadapi oleh klien, selain itu seorang perawat dapat berpenampilan menarik. Untuk itu seorang perawat memerlukan kemampuan untuk memperhatikan orang lain, ketrampilan intelektual, teknikal dan interpersonal yang tercermin dalam perilaku perawat. Saat ini perawat memiliki peran yang lebih luas dengan penekanan pada peningkatan kesehatan dan pencegahan penyakit, juga memandang klien secara komprehensif. Pelaksanaan Kesehatan dan Keselamatan Kerja (K3) adalah salah satu bentuk upaya untuk menciptakan tempat kerja yang aman, sehat, bebas dari pencemaran lingkungan, sehingga dapat mengurangi dan atau bebas dari kecelakaan kerja dan penyakit akibat kerja yang pada akhirnya dapat meningkatkan efisiensi dan produktivitas kerja. Keselamatan dan kesehatan kerja difilosofikan sebagai suatu pemikiran dan upaya untuk menjamin keutuhan dan kesempurnaan baik jasmani maupun rohani tenaga kerja pada khususnya dan manusia pada umumnya, hasil karya dan budayanya menuju masyarakat makmur dan sejahtera. Sedangkan pengertian secara keilmuan adalah suatu ilmu pengetahuan dan penerapannya dalam usaha mencegah kemungkinan terjadinya kecelakaan dan penyakit akibat kerja. Keselamatan dan kesehatan kerja (K3) tidak dapat dipisahkan dengan proses produksi baik jasa maupun industri. Perkembangan pembangunan setelah Indonesia merdeka menimbulkan konsekwensi meningkatkan intensitas kerja yang mengakibatkan pula meningkatnya resiko kecelakaan di lingkungan kerja.

Ruang lingkup k3 (Rachman, 1990) :

A. Kesehatan dan keselamatan kerja diterapkan di semua tempat kerja yang di dalamnya melibatkan aspek manusia sebagai tenaga kerja, bahaya akibat kerja dan usaha yang dikerjakan.

B. Aspek perlindungan dalam hyperkes meliputi : 
1) Tenaga kerja dari semua jenis dan jenjang keahlian

2) Peralatan dan bahan yang dipergunakan

3) Faktor-faktor lingkungan fisik, biologi, kimiawi, maupun sosial.

4) Proses produksi

5) Karakteristik dan sifat pekerjaan

6) Teknologi dan metodologi kerja

C. Penerapan Hyperkes dilaksanakan secara holistik sejak perencanaan hingga perolehan hasil dari kegiatan industri barang maupun jasa

D. Semua pihak yang terlibat dalam proses industri/ perusahaan ikut bertanggung jawab atas keberhasilan usaha hyperkes.

E.

\section{Peran perawat dalam meningkatkan K3}

a) a) Fungsi

1. Mengkaji masalah kesehatan

2. Menyusun rencana asuhan keperawatan pekerja

3. Melaksanakan pelayanan kesehatan keperawatan terhadap pekerja

4. Penilaian

b) Tugas

1. Pengawasan terhadap lingkungan pekerja

2. Memelihara fasilitas kesehatan perusahaa

3. Membantu dokter dalam pemeriksaan kesehatan pekerja

4. Membantu dalam penilaian keadaan kesehatan pekerja

5. Merencanakan dan melaksanakan kunjungan rumah dan perawatan di rumah kepada pekerja dan keluarga pekerja yang mempunyai masalah Ikut menyelenggarakan pendidikan K3 terhadap pekerja

6. Turut ambil bagian dalam usaha keselamatan kerjja

7. Pendidikan kesehatan mengenai keluarga berencana terhadap pekerja dan keluarga pekerja.

8. Membantu usaha penyelidikan kesehatan pekerja

9. Mengkordinasi dan mengawasi pelaksanaan K3. 
Fungsi seorang perawat sangat tergantung kepada kebijaksanaan perusahaan dalam hal luasnya ruang lingkup usaha kesehatan, susunan dan jumlah tenaga kesehatan yang dipekerjakan dalam perusahaan. Perawat merupakan satu-satunya tenaga kesehatan yang full time di perusahaan, maka fungsinya adalah :

a. Membantu dokter perusahaan dalam menyusun rencana kerja hiperkes di perusahaan

b. Melaksanakan program kerja yang telah digariskan, termasuk administrasi kesehatan kerja.

c. Memelihara dan mempertinggi mutu pelayanan perawatan dan pengobatan

d. Memelihara alat-alat perawatan, obat-obatan dan fasilitas kesehatan perusahaan.

e. Membantu dokter dalam pemeriksaan kesehatan sesuai cara-cara yang telah disetujui.

f. Ikut membantu menentukan kasus-kasus penderita, serta berusaha menindaklanjuti sesuai wewenang yang diberikan kepadanya.

g. Ikut menilai keadaan kesehatan tenaga kerja dihubungkan dengan faktor pekerjaan dan melaporkan kepada dokter perusahaan.

h. Membantu usaha perbaikan kesehatan lingkungan dan perusahaan sesuai kemampuan yang ada.

i. Ikut mengambil peranan dalam usaha-usaha kemasyarakatan

j. Membantu, merencanakan dan atau melaksanakan sendiri kunjungan rumah sebagai salah satu dari segi kegiatannya

k. Menyelenggarakan pendidikan hiperkes kepada tenaga kerja yang dilayani.

1. Turut ambil bagian dalam usaha keselamatan kerja.

m. Mengumpulkan data-data dan membuat laporan untuk statistic dan evaluasi.

n. Turut membantu dalam usaha penyelidikan kesehatan tenaga kerja

o. Memelihara hubungan yang harmonis dalam perusahaan

p. Memberikan penyuluhan dalam bidang kesehatan 
q. Bila lebih dari satu paramedis hiperkes dalam satu perusahaan, maka pimpinan paramedis hiperkes harus mengkoordinasi dan mengawasi pelaksanaan semua usaha perawatan hiperkes.

\section{Penerapan K3}

Penerapan K3 RS sudah merupakan keharusan dilaksanakan oleh manajemen rumah sakit, selain merupakan persyaratan akreditasi suatu rumah sakit, juga penting untuk meningkatkan mutu pelayanan / quality assurance rumah sakit. Selain hal dalam penerapan K3RS ditujukan agar dicapai suatu kondisi kerja dan lingkungan kerja rumah sakit yang memenuhi syarat K3 sehingga diperoleh peningkatan efisiensi kerja dan peningkatan produktivitas tenaga kerja rumah sakit. Upaya penerapan K3RS akan mencapai keberhasilan yang baik bila didiukung oleh seluruh komponen kerja di lingkungan kerja rumah sakit.

Tahapan-tahapan didalam penerapan K3RS di mulai dengan mengupayakan adanya :

a) Kebijakan Manajemen Rumah Sakit।

Kebijakan manajemen rumah sakit harus sesuai dengan komitmen manajemen rumah sakit, kesadaran akan pentingnya K3RS dan keyakinan mendukung kualitas pelayanan rumah sakit. Kebijakan manajemen K3RS / safety and health policy berfokus pada penilaian kerja / operasional rumah sakit dan penerapan K3 semua organisasi di rumah sakit. Pelaksanaan K3RS meliputi standar kerja RS, standar keamanan bangunan, standar peralatan, standar pengendalian / kondisi emergensi, standar pengolahan limbah dan lingkungan.

b) Pengorganisasian K3 Rumah Sakit

Pelaksanaan kebijakan K3 rumah sakit agar terlaksana dengan baik perlu dilakukan dalam bentuk organisasi dalam setiap rumah sakit dan memiliki kerja yang jelas serta adanya keterlibatan dna tingkatan komponen kerja di rumah sakit. Pengalaman menunjukkan suatu organisasi K3 tanpa program kerja yang jelas dan tidak didukung manajemen rumah sakit serta 
komponen kerja lainnya, akan merupakan kendalam di dalam penerapan K3RS. Organisasi K3 berada satu tingkat di bawah direktur dan bukan merupakan kerja rangkap. Adapun pengorgasisasian K3RS ada beberapa model yang pertama organisasi yang terstruktur dan bertanggung jawab kepada direktur rumah sakit. Bentuk organisasi K3 di rumah sakit merupakan organisasi struktural yang terintegrasi ke dalam komite yang ada di rumah sakit dan disesuaikan dengan kondisi/kelas masing-masing rumah sakit, misalnya komite medis/nosokomial kemudian yang kedua organisasi fungsional (non struktural), bertanggung jawab langsung ke direktur rumah sakit. Nama organisasinya adalah unit pelaksana K3 RS, yang dibantu oleh unit K3 yang beranggotakan seluruh unit kerja di rumah sakit.

c) Perencanaan dan Penerapan K3RS

Penerapan K3RS meliputi identifikasi faktor bahaya dan resiko yang diakibatkannya (Hazard identification and risk assessment) dan menentukan prioritas faktor bahaya serta mengurangi resiko bahaya yang ditimbulkan identifikasi faktor bahaya dan pengendaliannya sangat menentukan keberhasilan organisasi K3.

Untuk melaksanakan komitmen dan kebijakan K3 rumah sakit, perlu disusun strategi antara lain:

- Advokasi sosialisasi program K3 rumah sakit

- Menetapkan tujuan yang jelas

- Organisasi dan penugasan yang jelas

- Meningkatkan SDM profesional di bidang K3 rumah sakit pada setiapunit kerja di lingkungan rumah sakit

- Sumber daya yang harus didukung oleh manajemen puncak

- Kajian resiko secara kualitatif dan kuantitatif

- Membuat program kerja K3 rumah sakit yang mengutamakan upaya peningkatan dan pencegahan

- Monitoring dan evaluasi secara internal dan eksternal secara berkala 
- Perencanaan

KMK RI No.1087 / MENKES / SK / VII / 2010 menyatakan bahwa tujuan dari pelaksanaan K3RS yaitu:

1. Terwujudnya organisasi kerja yang menunjang tercapainya K3RS,

2. Meningkatnya profesionalisme dalam hal K3 bagi manajemen, pelaksana dan pendukung program,

3. Terpenuhi syarat $\mathrm{K} 3$ di setiap unit kerja.

4. Terlindunginya pekerja dan mencegah terjadinya PAK dan KAK,dan

5. Terselenggaranya program K3RS secara optimal dan menyeluruh.

\section{Penutup :}

Kebijakan rumah sakit dalam menerapkan sistem manajemen K3RS dalam bentuk surat kerja yang telah disusun dan diperiksa oleh direktur dan dibuat dalam bentuk tertulis yang diwujudkan dalam bentuk struktural organisasi tim K3RS yang memiliki tugas dan fungsi masing - masing. Pelaksanaan kesehatan dan keselamatan kerja rumah sakit tidak akan berjalan dengan baik jika direktur rumah sakit tidak menetapkan kebijakan untuk seluruh sumber daya rumah sakit. Untuk pengalokasian pendanaan telah dibuat sesuai dengan peningkatan sumber daya manusia dengan keahlian dibidang masing-masing dan pihak RS juga membuat pengalokasian pendanaan sesuai dengan pelaksanaan program K3 serta didalam pengalokasian anggaran dibuat dalam per 3 (tiga) bulan sekali dan dikoordinasikan kembali. Sebab suatu program K3 tidak akan terlaksanakan jika tanpa adanya pengalokasian pendanaan. Kebijakan K3 telah ditetapkan dan masih dalam proses perbaikan yang lebih baik lagi untuk mewujudkan sarana dan prasarana serta SDM yang lebih baik untuk melaksanakan K3. Semua anggota yang ada di struktur organisasi Komite Keselamatan dan Kesehatan Kerja RS terlibat didalam perencanaan kebijakan K3 dalam bentuk sumber daya yang berupa karyawan mendapatkan pelatihan K3. Peninjauan ulang kebijakan K3 akan dicapai dalam setiap tahun terlaksana sesuai dengan Permenkes No. 66 Tahun 2016. Kebijakan K3 ini sejalan dengan penelitian Sunandar (2017), dimana RS 
telah menetapkan kebijakan K3 secara tertulis terkait pelaksanaan Keselamatan dan Kesehatan Kerja (K3) yang ditanda tangani langsung oleh direktur. Kebijakan tersebut bersifat top down maksudnya pimpinan RS telah memiliki standar pelayanan K3 di Rumah Sakit, kemudian diadopsi dan disesuaikan dengan kondisi Rumah Sakit. Kebijakan tersebut di rumuskan oleh tim K3RS dan melakukan konsultasi dengan pihak pihak yang terkait, kemudian di usulkan ke direktur dan ditandatangani. Kebijakan tersebut ditembuskan keseluruh unit/pokja terkait, dikomunikasikan dalam bentuk sosialisasi atau kegiatan simulasi.Pihak K3RS juga melakukan tinjauan ulang kebijakan secara berkala untuk menyesuaikan kebijakan Keselamatan dan Kesehatan Kerja yang diterapkan Rumah Sakit dengan perkembangan kondisi Rumah Sakit dan perubahan peraturan perundangundangan. Perencanaan K3RS dilakukan untuk menghasilkan perencanaan strategi K3RS, yang diselaraskan dengan lingkup manajemen Rumah Sakit.Perencanaan K3RS tersebut disusun dan ditetapkan oleh pimpinan Rumah Sakit dengan mengacu pada kebijakan pelaksanaan K3RS yang telah ditetapkan dan selanjutnya diterapkan dalam rangka mengendalikan potensi bahaya dan risiko K3RS yang telah teridentifikasi dan berhubungan dengan operasional Rumah Sakit. Dalam rangka perencanaan K3RS perlu mempertimbangkan peraturan perundang-undangan, kondisi yang ada serta hasil identifikasi potensi bahaya keselamatan dan Kesehatan Kerja (Republik Indonesia Permenkes No. 66, 2016). Dalam perencanaan keselamatan dan kesehatan kerja rumah sakit Mitra Sejati melakukan suatu program tentang pedoman keselamatan dan kesehatan kerja rumah sakit. Perencanaan - perencanaan program yang dilaksanakan sudah ada ditetapkan dan memiliki pedoman dalam penanggulangan keselamatan dan kesehatan kerja di rumah sakit. untuk itu seorang perawat memerlukan kemampuan untuk memperhatikan orang lain, ketrampilan intelektual, teknikal dan interpersonal yang tercermin dalam perilaku perawat serta mengetahui fungsi dan peran seorang perawat dan disarankan berkerja dengan memperhatikan fungsi dan perannya tersebut. 


\section{DAFTAR PUSTAKA}

Ivana, A., Widjasena, B., Jayanti, S. (2014). Analisa Komiten Manajemen Rumah Sakit (RS) Terhadap Keselamatan Dan Kesehatan Kerja (K3) Pada RS Prima Medika Pemalang, Jurnal Kesehatan Masyarakat,2(1), 35-41.

Nazirah, R., Yuswardi. (2017). Perilaku Perawat Dalam Penerapan Manajemen Kesehatan dan Keselamatan Kerja (K3) Di Aceh. Idea Nursing Jurnal. 8(3). 2580-2445.

Purba, H. I., Girsang, V.I., Malay, U.S. (2018). Studi Kebijakan, Perencanaan Pelaksanaan Keselamatan Dan Kesehatan Kerja Rumah Sakit (K3RS) Di Rumah Sakit Umum (RSU) Mitra Sejati Medan Tahun 2018. Jurnal Mutiara Kesehatan Masyarakat,3(2),113-124.

Pratiwi, A., Hariyo, W., Sutomo, A. H. (2016). Komitmen Manajemen, Pengetahuan, Perilaku Dalam K3 Dan Kecelakaan Kerja Perawat Di Rumah Sakit Swasta Di Yogyakarta. Berita Kedokteraan Masyarakat, 32(11),415-420.

Republik Indonesia Permenakes No. 66. (2016). Keselamatan dan Kesehatan Kerja Rumah Sakit (K3RS). Berita Negara RI Tahun 2017. Nomor 38. Menteri Kesehatan RI. Jakarta.

Simamora, R. H. (2018). Buku ajar keselamatan pasien melalui timbang terima pasien berbasis komunikasi efektif: SBAR. Medan: USUpress.

Simamora, R. H. (2019). Buku ajar pelaksanaan identifikasi pasien. Uwais Inspirasi Indonesia.

Sucipto, C. D. 2014. Keselamatan dan Kesehatan Kerja. Yogyakarta: Gosyen Publishing.

Sembiring, S. F. (2018). Penerapan Keselamatan dan Kesehatan Kerja Di Rumah Sakit Umum Daerah Kabanjahe Kabupaten Karo Sumatera Utara. Skripsi FKM USU 
Suryana, A., Sutisna, A. (2016). Kesehatan dan Keselamatan Kerja. Jakarta: Kementerian Kesehatan Republik Indonesia.

Sunandar, Ibrahim. H, Damayanti,S.D, A.(2017). Gambaran Penerapan Standart Keselamatan dan Kesehatan Kerja Rumah Sakit Umum Daerah Haji Makassar, Public Health Science Journal, 9(2), 160-173. Universitas Islam Negeri Alauddin Makassar.

Tukatman., Sulistiawati., Purwaningsih., Nursalam., (2015). Analisis Keselamatan Dan Kesehatan Kerja Perawat Dalam Penanganan Pasien di Rumah Sakit benyamin Guluh Kabupaten Kolaka. Jurnal Ners 10(2),343-347. 